УДК 821.161 .2

Засць Г. В., аспірантка кафедри світової літератури та російського мовознавства Луганського національного університету імені Тараса Шевченка (м. Старобільськ)

\title{
ПОЕТИЧНИЙ СВІТОГЛЯД ВОЛОДИМИРА ЯРОШЕНКА
}

У статті розглянуто основні джерела формування поетичного світогляду В. Ярошенка. Визначено основні форми вираження авторської свідомості та своєрідність 
образної системи поетичних засобів В. Ярошенка-символіста. Проаналізовано філософськоестетичну кониепцію В. Ярошенка, його звернення до проблем відчуження людської особистості.

Ключові слова: ліричний герой, особистість, поезія, символізм.

B статье рассмотрены основные источники формирования поэтического мировоззрения В. Ярошенко. Определены основные формы выражения авторского сознания и своеобразие образной системь поэтических средств В. Ярошенко-символиста. Проанализировано философско-эстетическую конщепџию В. Ярошенко, его обращение к проблемам отчуждения человеческой личности.

Ключевые слова: лирический герой, личность, поэзия, символизм.

The article deals with the main formation sources of poetic outlook of V. Yaroshenko. The main forms of expression of the author's mind and originality of imagery system of poetic means of $V$. Yaroshenko as a symbolist were determined. The philosophical and aesthetic concept of $V$. Yaroshenko and his appealing to the problem of alienation of personality were analyzed.

Keywords: lyrical character, personality, poetry, symbolism.

Українська лірика 20-х років XX століття була гетерогенічною (різнорідною), дивуючи багатством талантів, розмаїттям стильових течій і форм поетичного моделювання світу думок і почуттів людини.

Паралельно й у складному поєднанні розвиваються імпресіонізм (В. Чумак, В. Еллан-Блакитний, М. Хвильовий), символізм (М. Філянський, Я. Савченко, П. Савченко, Д. Загул, В. Ярошенко, М. Терещенко), експресіонізм (Т. Осьмачка), неоромантизм (В. Сосюра, Ю. Яновський, М. Йогансен, О. Влизько), неокласицизм, конструктивізм (В. Поліщук), футуризм та інші модерні течії.

Твори того періоду сповнені романтики, патетичної інтонації, гіперболізму, «космізму», узагальненого образу маси. 3 усіх граней людського «я» оспівувались його політичні запити, ідейні переконання, беззастережне служіння справі революції. Інші грані свідомості і життя людини, зокрема й інтимні почуття, естетичні сприйняття, вважалися «гріхами» індивідуалізму. 3 часом цей аскетизм, особливо притаманний «пролетарським» митцям, долався. Українська поезія 20-x-30-х років минулого століття охоплює естетично всі багатства світу, його суперечності, трагізм буття людини у складному вирі подій. Завдяки своій мобільності поезія виступає на перше місце в українській літературі. Проходив інтенсивний процес тематичного оновлення лірики і їі жанрових форм. Передусім поети зосереджують увагу на 
героїко-романтичному оспівуванні української національної революції, на внутрішніх процесах народження нової людини, свідомого українця, захисника незалежної вітчизни [Ткачук 2011:17].

Актуальність обраної теми полягає в тому, що до цього часу не маємо чітко окресленого наукового аналізу щодо поетичного світогляду В. Ярошенка, творчість якого належить до малодосліджених наукових проблем сучасного літературознавства.

Метою нашої розвідки $є$ виявлення світоглядних домінант у поезії В. Ярошенка, обумовлених поглядом поета на людину і світ. Реалізація мети передбачає виконання таких завдань: розглянути основні джерела формування поетичного світогляду В. Ярошенка; визначити основні форми вираження авторської свідомості та своєрідність образної системи поетичних засобів В. Ярошенка-символіста; проаналізувати філософсько-естетичну концепцію В. Ярошенка, його звернення до проблем відчуження людської особистості.

Володимир Ярошенко народився у селі Яхники на Полтавщині, у сім’і вчителя. Рідна природа, селянські діти, книги, пісні матері, вимогливість батька - це ті фактори, що сформували світогляд майбутнього письменника.

Можемо припустити, що плідна співпраця у літературно-мистецькому об’єднанні «Музагет», у літературно-мистецькому тижневику «Мистецтво», у літературному підвідділі Всевидаву, в майстерні художнього слова при українському клубі «Боротьба» 3 П. Тичиною могли вплинути на світогляд В. Ярошенка. 3 цього приводу Я. Славутич зазначає, що часом у В. Ярошенка проглядають яскраві образи, що багатьма барвами нагадують раннього Тичину: «Випнулась в небі веселка - / Дужка святого цебра - / Нанизана на коромисело - / Райдужних кольорів гра» [Славутич 1998:66].

Н. Авраменко помічає мотив єднання поета із Космосом. У вірші «Одного разу» перша строфа створює картину вечірніх сутінків, доповнену чуттєвими та настроєвими барвами-обертонами: «Бліднула смужка далекого заходу, / Дими пахучі землю овіяли, / Віяли втіху, мовчазність і лагоду, - / Плід, щуо не сіяли. / Я захитався, обгорнутий нігою, / Хутко зірвався звіздою криштальною, / 
Блиснув на небі посмішкою-втіхою, / - Путтю дзеркальною. / Я - оповитий межою астральною; / Грації влюбленец̧ь, жертва ажурности - / Зв’янув в безмежности квіткою бальною, / Промінем жовтим в вечірній безжурності» [Ярошенко 1918:20].

Вечорова краса торкнула найглибші струни душі ліричного героя, викликала стан емоційного піднесення, горіння, він «хутко зірвався звіздою криштальною». Момент натхнення, осяяння, хоч і був дуже коротким (невдовзі після злету у небеса «оповитий межою астральною» герой-зірка погас, «зв'янув в безмежности квіткою бальною»), все ж подарував йому почуття радості від зближення із небесами: «Блиснув на небі посмішкою-втіхою, /Путтю дзеркальною».

У поезіях символістів простежується i намагання утвердити життя як діалектичну єдність: єдність протилежностей, єдність різноспрямованих начал. Для В. Ярошенка діалектика життя вкрай напружена, мінлива, постійно змінювана, це - континуальне розщеплення одного явища на багато інших та злиття безлічі різноманітних в одне: «Кожен промінь розпинається / На сім кольорів в мені, / Кожен колір загорається / На двоїстому вогні. // Ятрьохкутник - хрест розпятія / I спектральний потайник: / В смерку тайного зачатія / Світлий родиться двойник. // I як в морі відбивається / В чорній глибі-далечінь, / Так в мені всігди міняється / Світ i тінь» [Ярошенко 1918:18].

Ідея про те, що кожне явище має подвійну природу («Кожен колір загорається / На двоїстому вогні»), перенесена у світ суб'єктивізованого сприйняття, народжує нову ідею: справжня особистість ніколи не буває однозначною, «одноколірною», вона настільки багатогранна, як кількість кольорів у спектрі, i настільки непередбачувана, як їх мінливість, переливчатість.

У 20-х роках минулого століття лірика тяжіла до філософського трактування тих життєвих проблем, що мали вирішальне значення в історичній долі українського народу. Зокрема, порушуються вічні теми свободи і неволі, 
життя і смерті, людини і всесвіту, особи й колективу, й розв’язуються вони надзвичайно по-сучасному. Більшість поезій В. Ярошенка - це спроби філософськи осмислити людське буття, де головні мотиви - проблема відчуження людської особистості, пошуки надреальної істини крізь призму христологічних і природних символів («Відбились далі в душі моїй», «Гартовним кроком ступа життя», «Глядіть же, нові, у плодюче майбутнє», «Підковами брязнув дзвінко», «Рушу я в надзоряні шляхи» «Серце», «Уже на порозі» тощо). Глибоко філософське осмислення буття із християнськими узагальненнями й образністю репрезентує творчість письменника.

Мотив прожитого життя $є$ одним 3 найхарактерніших $\mathrm{y}$ поезії В. Ярошенка, котрий поєднується 3 темою безжально-невідворотного перебігу часу («Серце», «Дитинство», «Уже на порозі...» та ін.). Його символізують образи дороги, зими, порога та ін. Ліричний суб’єкт осмислює плин часу, безповоротні зміни, що супроводжуються зміною поколінь. Одні люди підуть зі світу, інші - прийдуть та почнуть нове життя.

Об’єктом рефлексії ліричного суб’єкта в поезії «Дитинство» є власний досвід, який відображено у спогадах про щасливе та безтурботне життя у дитинстві: «Дитинство! // Світла, золота пора... / О дні мої! // Яка кумедна заздрість, / I запізнілий сум, і запізніла радість, / I хороше, і боляче згадать про вас тепер» [Ярошенко 1968:97].

Спогади про дитинство викликають у ліричного героя неоднозначні відчуття як радості за надану можливість пережити щасливі моменти, так і сум через те, що ці хвилини безтурботного життя ніколи не повернуться.

Отже, індивідуально-екзистенційний час, що осмислює ліричним суб’єктом, ніби розпадається на щасливу пору дитинства і зрілості, неодмінно обтяжену розчаруваннями, досвідом складних життєвих випробувань, стражданнями.

Домінуюче емоційне забарвлення поезій відтінками суму, меланхолії, а іноді навіть і розпачу. 
У вірші «Сірим днем душа моя розквітне» ліричний суб’єкт, розмірковуючи про своє безбарвне життя, усвідомлює, що він самотній та $є$ чужим для оточуючих, яким не довіряє. I лише єдиною надійною підтримкою для ліричного героя виступають його витвори: «Я дивлюсь на них чужий $i$ обережний / I не вірю їм, як скажуть, щуо мої... / Я один, я одинокий, я бентежний, / Я сховавсь за витвори свої» [Ярошенко 1918:5]. Песимізму додає думка ліричного героя про те, що життя завжди буде сірим та сумним: «Сірим днем душа моя розквітне / В тужні звуки $і$ в печальні барви... / Я не марю про життя блакітне, / Я про вквітчані не марю нари» [Ярошенко 1918:5].

Поширеним у поезії митця $є$ сірий колір, що символізує недовіру, самотність, меланхолію, печаль та депресію («Сірим днем душа моя розквітне...» [Ярошенко 1918:5], «Сірий день байдужим кроком / Йде належну тайну путь...»[Ярошенко 1918:5], «Відбились далі в душі мойй, / У сірім колі вони цุвітуть... Дивлюся в душу - вона летить, / Як сіра птиця - німа печаль» [Ярошенко 1918:8], «День родивсь сьогодні сірим... / Та печаль, як сіра птиия, / Цілий день кружляла в далях... / Вмре пораненая птиця, - / Сірий - стане білим щуастям» [Ярошенко 1918:10], «Може йдуть повз мене лагідні душі сірі, рідні, томлені...» [Ярошенко 1918:12], «Ми сірієм в смерку плямами...»[Ярошенко 1918:13], «А на крем'янияі сіро і сухо...» [Ярошенко 1918:16] тощуо).

В усі часи та епохи поети не раз замислювались над питанням: «А що ж таке Людина за своєю суттю?» Символісти відкинули погляд на людину з точки зору об’єктивної реальності, оскільки вважали іiі джерелом породження ворожого їхньому сприйняттю позитивізму. Для них людина сама по собіреальність, а усвідомлення себе такою доводило іiі неповторність, самобутність, самоцінність.

Саме це прагнув передати у своїй поезії В. Ярошенко: «Залякана в повітрі блудить блакіть... / Не вірте часу універсалям: / Палю візьміть - / I по скрижалям! // Золоті зорі, як рої ос, / Гудуть вгорі, у синьому морі... У покос / 
Зорі! // Над груди будинків, / Над неба котурни, / Над силу і вік, / Над вимір годинників, / Над урни - / Чоловік!» [Ярошенко 1919:17].

Поезії В. Ярошенка властиве трагічне світовідчуття. Наявні мотиви душевної спустошеності, скорботи, всеохопного смутку. Настроєво споріднені 3 цими творами мотиви втоми життям розгортаються у віршах «Відбились далі в душі моїй...», «Сірий день байдужим кроком...», «Ми». Останній вірш засвідчує характерне для символістів ставлення до смерті як до відпочинку від земних страждань: «I умрем в великім щастеві / - B смерку ніжнім віск дотанувший - / Тихі, сіро-попелястові, / Жальним зором в далі глянувши...» [Ярошенко 1918:13]. Художня структура поезій, що розкривають трагізм буття людини у світі, де панують сили зла, глибину екзистенційної суперечності між ідеалом і дійсністю, визначається поєднанням біблійної символіки.

Характерний для поезії митця трагізм буття зумовлюється переважно конкретними земними причинами, трагічна доля творчої особистості у його поезії не має трансцендентного характеру, наперед визначеного вищими силами. Ліричний суб'єкт страждає через безнадійність, неможливість знайти однодумців, самотність, нездатність оточення зрозуміти високе мистецтво («Сірим днем...», «Сірий день байдужим кроком...», «Знову сам i знов печальний...», «Відбились далі в душі моій...», «Безнадійність», «Мої надії літали...», «Обійма мою душу печаль...»).

У двадцяті роки серед поетів була поширена особлива зневага до міста 3 неукраїнським населенням, що своїми росіянізаторськими струмами підточувало сильне українське село. Це відбилося у творчості В. Ярошенка, який розумів небезпеку російщення: «... сьогоденні міста, / Сирени зойк, автомобілі / Серед міської фістули / Мене в провулку придавили / I на дротах розіп'яли. // Сказали: корчся!» [Славутич 1998:66].

У поетиці митця відзначається селянський світогляд. Поет явно віддає свою любов рідному селу. I хоч тепер, мовляв, багато таких, що «розчахнулися», він сповнений оптимізму та віри в незнищенність українського 
народу: «Ми ляжем ситим перегноєм / Під коренищза молоді / I виразки в свої загоїм / Об вруна тепло-золоті» [Славутич 1998:66].

В. Ярошенко, будучи вихідцем із села, любив природу та захоплювався іiі красою. Замилування природою знайшло своє художнє втілення у пейзажній ліриці поета, що наповнена натурфілософськими міркуваннями ліричного героя. Природа поетом одухотворюється, залишаючись у вічних зв’язках стихій, у своїй холодній величі й таємничості.

У вірші «У мене місяць - разок намиста» відбито роздуми ліричного героя, який порівнює місяць прожитого життя 3 намистом, що складається 3 тридцяти намистин, тобто днів, або 3 килимом 3 листя, що впали 3 тридцяти дерев. Кожен новий день ліричного суб'єкта має очі «одні, як сонце, другі, як ночі» [Ярошенко 1919:62]. Ліричний герой зізнається у тому, що іноді приємно згадати минуле, але часом виникає відчуття пригнічення через неможливість його повернути: «Але буває любо, любо / Торішнє листє ворушить / I меж листками клена й дуба / Холодну жабу роздушить» [Ярошенко 1919:62]. Поезія демонструє органічне поєднання людини 3 природою.

У поезії «Сула» річка виступає не звичайним фоном для рефлексії ліричного героя, а стає свідком людського горя та страждань: «Oй-же, Суллі бистрі хвилі! / Скільки вас у синім морі, / Скільки ока із могили, / Стільки й в людях того горя./ / Над Сулою над одною, / Над шумливою рікою, / Стільки й моря не зміряно, / Скільки горя посіяно». Ліричний герой вказує на кривдників, які заподіяли лиха українському народові: «Посіяно й поливано / Татарином незчислимим, / Половчанином бистроверхим, / I вельможним паном-ляхом, / I московським генералом» [Ярошенко 1968:20].

Ліричний герой разом із річкою пропускає крізь свою душу біль та страждання українського народу. Природа трактується як невід’ємна іпостась гармонійного буття людини у всесвіті.

У поезії В. Ярошенка простежується календарна тематика. Кожна пора року викликала своєрідні асоціації, налаштовувала ноти душі на особливий лад, народжувала в уяві неоднозначні образи. Широковживаними є образи весни: 
«Веснянка», «По небу не хмари, а клоччя», літа: «День легкий, як шовкова тканина», «Купальські білі берези», «Взялись рови полинями», осені: «Осінь», «В сутрівожні години згасання», зими: «Зимовий пейзаж», «Проти мого вікна дріма дебелий граб», що виступають в узагальненому значенні або конкретизуються соціальними та особистісно-психологічними мотивами.

Образи природи у поезії митця - це насамперед знаки настроїв, понять, ідей. Важливу світоглядно-естетичну функцію виконує міфологічний образ сонця - символ творчої енергї життя («Вечірня соната»). У поезії «В сутрівожні години згасання» завершення дня символізує настрої, викликані усвідомленням того, що «вечір» приносить із собою відчуття втоми, печалі, жорстокої туги щодо усвідомлення невідповідності світу своїх мрій, сподівань iз реальністю. Життєствердна настроєва забарвленість властива символіці ранку - оновлення, надія на краще («Ранком, ранком, зо світанком...»).

Вважаємо, що на формування поетичного світогляду митця вплинуло багато факторів - це виховання, освіта, любов до природи, оточення, політична ситуація, релігія, що поєдналися в поетичній свідомості В. Ярошенка напрочуд своєрідно. Мотиви туги, суму, смутку, печалі залишили помітний слід у творчості митця. Настрої суму в поезії підкреслюються сірим кольором. Об’єктом поетичного дослідження митця була особистість, iii переживання, ïi світовідчування, що передавалися інтуїтивно.

\section{БІБЛІОГРАФІЯ}

Славутич 1998 - Славутич Я. Розстріляна муза: твори / Я. Славутич. Київ, 1998. - 494 с.

Ткачук 2011 - Ткачук М. Відродження української літератури 20-х років XX століття [Електронний ресурс] / М. Ткачук // Курс лекцій для студентів філологічного факультету зі спеціальності українська мова та література. Режим доступу : http://www.twirpx.com/file/608369/

Ярошенко 1919 - Ярошенко В. Луни: Поезії / В. Ярошенко. - Київ, 1919. - Кн. 2. -70 c. 
Ярошенко 1918 - Ярошенко В. Світотінь. Поезії / В. Ярошенко. - Київ : Сяйво, 1918. Кн. 1. - 46 с.

Ярошенко 1968 - Ярошенко В. Степ: Поезії. / В. Ярошенко. - Київ, 1968. $120 \mathrm{c}$. 